\title{
Are the Czech or Slovak regions "closer to Europe"? Pro-Europeanness from a subnational perspective
}

\section{Martin Plešivčák*}

Comenius University in Bratislava, Faculty of Natural Sciences, Department of Economic and Social Geography, Demography and Territorial Development, Slovakia

* Corresponding author: martin.plesivcak@uniba.sk

\begin{abstract}
Based on the 2003-2019 electoral data, this article evaluates the level of pro-Europeanness in Czechia and Slovakia at the regional and sub-regional levels during and after their EU accession period. The TOPSIS multi-criteria evaluation method and cluster analysis were used to quantify the pro-European levels and to create the subsequent categories of territorial units. The results show support for the ideas of European integration primarily in large urban regions (Prague, Brno, Bratislava, Košice), territorial units with a higher concentration of ethnic minorities, larger scale agricultural activities (southwestern Slovakia), and a high degree of religiosity (northeastern Slovakia). The low level of pro-Europeanness was predominant in the less developed north-western Czechia and parts of Moravia. In Slovakia, the Eurosceptic regions were mostly located in the northwest, where the values of statism, egalitarianism and nationalism have a strong tradition. This approach can be used to identify areas of weak support for the EU project at a spatially disaggregated level in other EU countries.
\end{abstract}

\section{KEYWORDS}

Pro-Europeanness; TOPSIS method; EU referendum; European Parliament elections; subnational level; Czechia; Slovakia

Received: 4 October 2019

Accepted: 16 July 2020

Published online: 30 September 2020

Plešivčák, M. (2020): Are the Czech or Slovak regions "closer to Europe”? Pro-Europeanness from a subnational perspective. AUC Geographica 55(2), 183-199 https://doi.org/10.14712/23361980.2020.13

(C) 2020 The Author. This is an open-access article distributed under the terms of the Creative Commons Attribution License (http://creativecommons.org/licenses/by/4.0). 


\section{Introduction}

Czechia, Slovakia and eight other mainly post-socialist countries of Central and Eastern Europe, joined the European Union on May 1, 2004. In the periods before and after accession, the moods in the two countries in relation to the European integration project differed based on time, location, and the political and socio-economic conditions. Public support for the country's accession to the EU, as well as the referendum turnout itself differed for both countries, depending on their intraregional specifics. The same can be said for the period after May 1, 2004, in the case of the territorial specificities of turnout and votes for Eurosceptic parties in the European Parliament (EP) elections.

We have seen a gradual shift of Euroscepticism toward the centre of European politics since the 1990s. Nevertheless, it gained stronger influence after both enlargement and elections in 2004. For the new member states, there was high public support for the European Union project; however, it began to decline after accession. In addition to contextual factors such as the financial and migration crises, changes in the rhetoric of several political actors could have contributed to the rise of Euroscepticism. The extreme right-wing political parties learned from the past and instead of proclaiming radical views (including xenophobia, racism and anti-Semitism) they moved on to a somewhat milder and more tolerant populism and thus Euroscepticism was addressed to a wider electorate (Goodwin 2011). The bearers of pro-European values or Euroscepticism include citizens on the one hand, and their political representatives, political parties and specific candidates on the other.

The main objective of this contribution is to identify the degree of pro-Europeaness of the public in Czechia and Slovakia at the time of accession to the EU and afterwards at the hierarchically lower, regional and sub-regional (district) levels, to create a typification of partial territorial units according to the long-term pro-European orientation and to characterize the groups formed on the basis of its indicators. For this reason, we apply TOPSIS multi-criteria decision making method regarding the value distance of given territorial unit to the most positive and most negative value within the set of units under study. We also try to outline possible factors related to pro-Europeanness at the regional and district levels, discussing with findings of previous studies on electoral behaviour (e.g. Krivý et al. 1996; Madleňák 2012; Pink 2012; Voda 2015; Kostelecký et al. 2016; Przybyla 2019). Thus, the aim is to map the "Europeanity" of the sub-national units of these countries, which is particularly important in relation to running an effective, place-specific campaign focusing on EU relevance and benefits, the meaningful dissemination of its promotional activities, and in the context of regional (cohesion) policy, also due to the proper direction of real assistance from European structural and investment funds. Indeed, if we want to avoid disintegration processes within the EU and the threat of its gradual decomposition, just in those regions which are characterized by the highest degree of Euroscepticism, the EU's contribution to the future should be the most visible. This is prevented by the knowledge of "problematic" regions and the reasons that can cause Euroscepticism at the regional and sub-regional levels.

\section{Theoretical background}

The dominant concept of understanding European politics, in the case of European elections, is the second-order national election theory (Reif and Schmitt 1980). European Parliament elections were characterized as national elections taking place simultaneously in all the member states of the European Community. These are less important elections held in the shadow of major (general) national elections and are dominated by the same parties that focus more on national interests than European issues or on the position of the national parties to the EU (Hix and Marsh 2011). Nevertheless, the results of the national and European elections are still different. Second-order elections do not lead to national government formation and are therefore of less interest to voters, the media and political actors. This leads voters to make a different decision than if the national elections were organized on the same day (Hix and Marsh 2011). The electorate votes on the basis of what they think about the country's economic situation, the government's performance or the topics that move domestic politics at that moment (Carrubba and Timpone 2005; De Vries et al. 2011). For this reason, the campaigning and tactics of political parties in second-order elections are motivated by national themes (Reif and Schmitt 1980; Cabada 2010). Also, media coverage of these elections is usually limited. Furthermore, immediately after the election and the end of the campaign, the European Parliament returns to obscurity (Lodge 2010). In the analysis of the first European elections (1979), there is emphasized the fact that one of the main aspects of the second-order elections is that there is less at stake (Reif and Schmitt 1980). The election does not involve the national parliament or the government, and the electorate is not highly motivated to participate in the election or to vote differently than they would if national elections were held. The second order election theory predicts that elections to the European Parliament follow three main formulas: a lower rate of participation (lower turnout), a more positive outcome for small and new parties, and a loss of support for government parties stemming from the location of general elections in the national election cycle (Reif and Schmitt 1980; Hix and Marsh 2007). The validity of the theory in the context of post-socialist countries has been addressed by several authors, e.g. Linek et al. 
(2007), Šaradín (2008), Havlík and Hoskovec (2009), Cabada (2010), Klíma and Outlý (2010), Kovář (2013), Kovář and Kováŕ (2014).

In order to understand the perception of the nature of the European Parliament elections by the political actors themselves (parties, politicians and voters), the connection of these elections with the concept of Europeanization must be recognized. Europeanization is defined as a process of changing the direction and content of politics in such a way that the political and economic dimensions of the European Community influence the structure of national politics, and shape the content and scope of national policies (Landrech 2002). It is clear that European issues have an increasing effect on political debates at the national level, but the response of national party systems is very limited, without a more significant formation of (new) parties built on a "European basis". In this context, it is worth mentioning the term "European cleavage", around which the pre-election struggle of the political actors involved in the existing social structure should ideally be shaped (ideally, real awareness of the dimension of the "Europeanness" concerning these elections). The term European cleavage, in contrast to the more traditional concept of cleavages (Lipset and Rokkan 1967), can in principle be defined as a concept for and against a territorial integration project within Europe (the EU as a centrally oriented and bureaucratic superstate, with a common economic or financial (monetary, fiscal or budgetary) policy on the one hand, or as a concept of a more lenient bundle of states, for example on a customs union basis or the existence of a common market, on the other). According to Bartolini (2007), this term can be understood on three levels: general (for and against the EU as a territorial integrator $=$ independence $/$ integration dimension), constitutive (the cultural level - who can access, division of competences between EU institutions and member states themselves, community decision-making mechanism) and isomorphic (ideological issues - liberalism, protectionism, welfare state, immigration policy, civil rights, etc.). We could assume that those who evaluate the process of European integration in their particular life as a disappointment tend to ignore the European Parliament elections, or they use the protest vote against the mainstream parties and support Eurosceptic political forces of an extreme right- or left-wing orientation.

The question remains regarding how much of the electorate and the political parties in the European Parliament elections place an emphasis on addressing internal political issues and how much the current challenges of European integration or the content of European policies themselves matter. There is, however, evidence that the Eurosceptic and pro-European parties place importance on European issues, and this approach has ideological and practical significance in terms of better electoral results. An election campaign for the European Parliament features a mix of domestic and European issues, which was confirmed in the first direct elections in 1979 (Blumer 1983; Charlot 1986). Nevertheless, their importance varies from election to election and from place to place. In general, however, the importance of European themes gains momentum over time, but this is in contrast to the declining voter participation in the European elections. Traditional issues, such as research and development, food security, environment, foreign policy, immigration, and economic and industrial policy may be considered as "more European" (Budge 2001; Robert Schuman Foundation 2004). Nevertheless, the current pan-European themes of the given period, such as, the economic and financial crisis, Greece's debt crisis, Brexit, migration, reviving debates on the concept of a two-speed Europe, the future of EU regional policy, etc., as well as the hot topics of the domestic political scene, or analyses of election results in key European integration countries play a no less important role in this context.

In general, five basic forms of party Euroscepticism can be identified (Kopecký and Mudde 2002; Taggart and Szczerbiak 2002). The first category concerns major and government parties with a critical attitude towards the definition of European policies as regards the functioning and direction of the Community itself This moderate form concerns the attitude of the social democratic parties toward the inadequate implementation of the socially oriented EU program, while the stronger form is represented by conservative or neoliberal parties who call for less regulation and intervention by EU institutions. It therefore has a more ideological character. The second type of Euroscepticism also concerns government parties and deals with the European integration project in terms of a reasonable (or necessary) degree of Brussels interventions in policies implemented at the national level. It is therefore a pragmatic debate on the division of competences and agendas between EU institutions and member states. The third type of Euroscepticism is represented by a radical opposition to mainstream and government parties, in the sense of protest and enforcing one's own, far-right or far-left-oriented ideology, in the sense of maintaining national interests and identity on the one hand, and protesting against excessive liberalization of the public sector and economic relations with negative social consequences on the other. The fourth category of Euroscepticism is aimed at fundamentally restoring the functioning of the Community as a whole, the policy of exiting or refusing entry to the EU. However, in principle, parties of this type do not have a significant political impact on the domestic scene, but, somewhat paradoxically, in some countries they enjoy a more prominent role particularly in the European Parliament elections. The last type of Euroscepticism is relatively marginal in terms of political representation and time span, and is often connected to specific persons or "single use" parties. These formations do not require a fundamental reform of 
relations within the EU but rather focus on subtle topics such as transparency and accountability for the staff of EU institutions, effective use of EU resources, salaries of MEPs, etc.

\section{Methodology}

In the empirical part of the paper, we use two types of electoral geographic data: the referenda on the country's accession to the EU in 2003 ("yes to EU") and the European Parliament elections held in 2004, 2009, 2014 and 2019. In the second, we also work with the results of the Eurosceptic parties. We put them into this group based on the work of several authors and electoral programs of the parties themselves. In the case of the Czech political situation, we used several studies for the inclusion of the parties (Bradová and Šaradín 2004; Baun et al. 2006; Fiala et al. 2006; Linek et al. 2007; Havlík 2008; Havlík and Vykoupilová 2008; Hloušek and Pšeja 2009; Hricová 2009; Havlík 2010; Kovár 2014). In the case of Slovakia, we also used relevant literature for this purpose (Gyárfášová and Velšic 2004; Gyárfášová 2007). We refer to geographical context of electoral support for the parties in European elections (Plešivčák 2015) and the spatial differentiation of the extreme right support (Mikuš and Gurňák 2016; Mikuš et al. 2016). The character of the electorate was the decisive criterion for the inclusion of a political party among the group of Eurosceptic parties. Recessive parties were not taken into account. Given the above division of parties into types according to the degree of Euroscepticism and their relevance within the party system, we would like to mention the cases when the inclusion of parties to the Eurosceptic, or their exclusion, was a problematic matter. We emphasize that in classifying the parties, we primarily took into account the nature of the party's electorate rather than the official rhetoric of its then leaders. Among other parties, in the case of the Czechia, we also considered KSČM (2004-2019) and Úsvit (2014) to be the Eurosceptic parties (more precisely parties with a predominantly Eurosceptic electorate), although some authors label them soft Eurosceptic (Havlík and Kaniok 2006; Kaniok and Havlík 2016). The electorate of these two parties is indeed quite different from another party often associated with Eurospeticism, ODS (Občanská demokratická strana, eng. Civic Democratic Party). In the case of this party, we finally decided to not include it in the Eurosceptic Party Group, based on several arguments (Baun et al. 2006), as this party can rather be perceived as "pro-European with reservations". Given the ODS electorate, which is largely characterized by more educated voters living in the urban environment more in favour of the EU project, we have chosen not to include the party into the Eurosceptic group. In the case of Slovakia, there was a problem with LS-HZDS and SNS, parties that even expressed support for the
EU at the time ("at the last minute"); but L'S-HZDS's policies in office as well as the profile of the then and later electorate, along with SNS and later especially L'S-NS (L'udová strana - Naše Slovensko, eng. People's Party - Our Slovakia) proved to be Eurosceptic to the largest extent when comparing all of the major political parties in Slovakia (Gyárfášová 2007). Even in the case of the European Union membership referendum in 2003, a low turnout (52\%) demonstrably confirmed the fact that Euroscepticism in Slovakia was also present in the past (in comparison with the current L'S-NS at the time of the impending membership in a more latent form). We do not consider it to be strictly correct and the only possible to refer to the divisions of various authors in this matter, as e.g. Hynčica and Šárovec (2018) describe the SaS as a Eurosceptic party, while a large part of its electorate supports the EU project. We also consider it relatively subjective to perceive parties such as KDH or SMER-SD (Henderson 2008) as Eurosceptic, even for the 2004 European Parliament elections. With these examples we wanted to illustrate the fact that the classification of parties as Eurosceptic is really a very problematic and to some extent subjective matter, in which different authors can work with different set of Eurosceptic parties in research, as a certain degree of subjectivity of classification is not possible to avoid.

For each election of the period under study (20042019), we identified the following parties as Eurosceptic parties:

\section{Czechia}

2004 European Parliament Elections - DS (Dělnická strana, eng. Workers' Party), KSČM (Komunistická strana Čech a Moravy, eng. Communist Party of Bohemia and Moravia), NARKOA (Národní koalice, eng. National Coalition), NEZ (Nezávislí, eng. Independent), RMS (Republikáni Miroslava Sládka, eng. Republicans of Miroslav Sládek)

2009 European Parliament Elections - DS, KSČM, Libertas.cz, NS (Národní strana, eng. National Party), SSO (Strana svobodných občanů, eng. Party of Free Citizens), SPR-RSČ (Sdružení pro republiku - Republikánská strana Československa, eng. Association for the Republic - Republican Party of Czechoslovakia), Suverenita (eng. Sovereignty)

2014 European Parliament Elections - Česká suverenita (formerly Suverenita, eng. Czech Sovereignty), DSSS/SPE (formerly Dělnická strana, Dělnická strana sociální spravedlnosti/Ne diktátu Bruselu!, eng. Workers' Party of Social Justice/No to Brussels Dictate!), KSČM, KSČ (Komunistická strana Československa, eng. Communist Party of Czechoslovakia), ND (Ne Bruselu - Národní demokracie, eng. No to Brussels - National Democracy), RSČMS (Republikánská strana Čech, Moravy a Slzska, eng. Republican Party of Bohemia, Moravia and Silesia), SSO, SZR-NE (Strana zdravého 
rozumu - Nechceme Euro, eng. Party of Common Sense - We Don't Want the Euro), Úsvit prúmé demokracie (eng. Dawn of Direct Democracy)

2019 European Parliament Elections - ANS (Aliance národních sil, eng. Alliance of National Forces), APAČI (Alternativa pro Českou republiku, eng. Alternative for Czech Republic), Česká suverenita, Svobodní/Radostné Česko (eng. Independents/Joyful Czechia), ČSNS/Patrioti ČR (Česká strana národně sociální/Patrioti České republiky, eng. Czech National Social Party/Patriots of Czech Republic), KOAL (Konzervativní alternativa, eng. Conservative Alternative), KSČM, Moravané (eng. Moravians), První republika (eng. First Republic), SNČR (Strana nezávislosti České republiky, eng. Independence Party of the Czech Republic), DSSS/NF (Dělnická strana sociální spravedlnosti/Národní fronta, eng. Workers' Party of Social Justice/National Front), SPD - Tomio Okamura (formerly Úsvit přímé demokracie, Svoboda a přímá demokracie - Tomio Okamura, eng. Freedom and Direct Democracy - Tomio Okamura), SPR-RSČ, Rozumní/ND (formerly SZR, eng. Reasonables/Národní demokracie, formerly Právo a Spravedlnost, eng. National Democracy)

\section{Slovakia}

2004 European Parliament Elections - KSS (Komunistická strana Slovenska, eng. Communist Party of Slovakia), L'S-HZDS (L'udová strana - Hnutie za demokratické Slovensko, eng. People's Party - Movement for Democratic Slovakia), SL'S (Slovenská l'udová strana, eng. Slovak People's Party), SNS/PSNS (Slovenská národná strana/Pravá Slovenská národná strana, eng. Slovak National Party/True Slovak National Party)

2009 European Parliament Elections - KSS, LS-HZDS, SNS

2014 European Parliament Elections - KSNS (Krestanská slovenská národná strana, eng. Christian Slovak National Party), KSS, LS-NS (L'udová strana Naše Slovensko, eng. People's Party - Our Slovakia), NaS-NS (Národ a Spravodlivost' - naša strana, eng. Nation and Justice - Our Party), SL'S, SNS, Úsvit (eng. Dawn), Vzdor - strana práce (eng. Defiance - Labour Party)

2019 European Parliament Elections - Kotleba LSNS (formerly L'udová strana - Naše Slovensko, eng. Kotleba - People's Party Our Slovakia), KSS/Vzdor strana práce, SL'S Andreja Hlinku (formerly SL'S, eng. eng. Slovak People's Part of Andrej Hlinka), SME RODINA - Boris Kollár (eng. We Are Family - Boris Kollár), SNJ-sv (formerly KSNS, Slovenská národná jednota strana vlastencov, eng. Slovak National Unit - Patriot Party), SNS

We wanted to approach the issue from a positive perspective, based on support for the EU project (Euro-optimistic), and not Euro-sceptically. Therefore, we decided to work with the index of pro-Europeanness. When constructing, in addition to supporting EU accession by Referendum 2003, we considered supporting Eurosceptic parties, as is commonly used. We could not automatically work "with the rest" (100 per cent minus the support for the Eurosceptic parties) as a \% for pro-Europeanness, as a much wider group of parties would include much more heterogeneous political entities (in relation to the level of EU support) than for parties defined as Eurosceptic. The settings of the model calculation in the TOPSIS method technically solve this "discrepancy" (index of pro-Europeanness vs. votes for Eurosceptic parties) very easily and is based on evaluating the influence of input variables with sensitivity to their orientation (increasing value of something "negative" means a decrease in the value of index of pro-European and vice versa. The researcher sets the desired orientation of the variable - for our research a positive orientation in supporting the country's accession to the EU, and a negative orientation in supporting the Eurosceptic parties, which in both cases means increasing the value of the index of pro-Europeanness).

The variables entering the index of pro-Europeanness thus were as follows:

a) Votes for accession to the 2003 European Union referendum (\%) - the more the better

b) Votes for Eurosceptic parties in the 2004 European Parliament elections (\%) - the less the better

c) Votes for Eurosceptic parties in the 2009 European Parliament elections (\%) - the less the better

d) Votes for Eurosceptic parties in the 2014 European Parliament elections (\%) - the less the better

e) Votes for Eurosceptic parties in the 2019 European Parliament elections (\%) - the less the better

We obtained data for the state, regional and district levels from the databases of the Czech Statistical Office and the Statistical Office of the Slovak Republic (Czech Statistical Office 2019; Statistical Office of the Slovak Republic 2019).

We use the TOPSIS method (Technique for Order Preference by Similarity to Ideal Solution) to evaluate the position of the regions and districts under study in mutual comparison based on the values of the set of indicators mentioned above. This method generates score for the index of pro-Europeanness to rank the mentioned territorial units. For the need of the empirical part of the paper, we decided to use this method, which in relation to the objectives of the work can be assessed as adequate (for this reason, it was not necessary to use other methods, e.g. factor analysis). Given that in this part of the paper we decided to evaluate a set of variables indicating the degree of pro-Europeanness across the regions and districts of Czechia and Slovakia, the use of TOPSIS method as one of the multicriteria evaluation tools can be considered 
desirable. In addition, if we work with several territorial units, in this case 20 at the regional and 149 at the district level, the use of this method is the right choice, because in the case of a given territorial unit it takes into account the level of each input variable to ideal and to the least desirable value within the set of units (i.e. with respect to the value of the most successful and the least successful region or district).

Accelerators increasing the value of the pro-Europeanness index were the high values of indicator $a$ (the higher the better) and the low values of indicators $b-e$ (the lower the better). When calculating index (in scale from 0 to 1 ), each input indicator $(a-e)$ was equally weighted, by $1 / 5(0.2)$.

The TOPSIS method (Hwang and Yoon 1981) is considered one of the most classical multi-criteria decision making methods (Opricovic and Tyeng 2004; Shih et al. 2007; Manokaran et al. 2011).

It constitutes a collection of shortcut methods designed to minimize the distance from the ideal solution. These methods use an ideal variant as the object of aspiration. The selected "best" compromise variant is then the one which according to the selected metrics is the closest to the ideal option.

It provides a complete ordering of all variants. To resolve the problem, the multi-criteria decision matrix as well as the weight vector of individual criteria has to be determined. The main principle of this method is to identify the variant that is closest to the positive ideal solution, and farthest from the negative ideal solution.

The calculation procedure is as follows.

1. To calculate the normalized multi-criteria decision matrix

$R=\left(r_{i j}\right)$

using the formula:

$$
r_{i j}=\frac{y_{i j}}{\left(\sum_{i=1}^{p}\left(y_{i j}\right)^{2}\right)^{\frac{1}{2}}}, i=1,2, \ldots, p, j=1,2, \ldots, k
$$

After this transformation, the columns in the matrix are vectors of unit size by Euclidean metrics.

2. To calculate the weighted multi-criteria decision matrix

$W=\left(w_{i j}\right)$

how the $j$-th column is multiplied by the appropriate weight, as follows

$$
w_{i j}=\left(v_{j} r_{i j}\right)
$$

3. To determine the positive ideal solution

$$
H_{j}=\left(\max _{i} w_{i j}\right), j=1,2, \ldots, k
$$

and the negative ideal solution

$$
D_{j}=\left(\min _{j} w_{i j}\right), j=1,2, \ldots, k
$$

4. To calculate the distance from the positive ideal solution by using the formula as follows:

$$
d_{i}^{+}=\left(\sum_{j=1}^{k}\left(w_{i j}-H_{j}\right)^{2}\right)^{\frac{1}{2}}, i=1,2, \ldots, p,
$$

and from the negative ideal solution by using the formula below:

$$
d_{i}^{-}=\left(\sum_{j=1}^{k}\left(w_{i j}-D_{j}\right)^{2}\right)^{\frac{1}{2}}, i=1,2, \ldots, p,
$$

The Euclidean distance measure was utilised to calculate the distance.

5. To calculate the relative distance from the negative ideal solution by using the formula below:

$c_{i}=\frac{d_{i}^{-}}{d_{i}^{+}+d_{i}^{-}}, i=1,2, \ldots, p$

Variants are then arranged in descending order according to the $c_{i}$ values.

Subsequently, we used the cluster method to create groups of districts based on the pro-Europeanness index (Hastie et al. 2016). The increasing amount of data and information has led to the need to develop methods to clarify and classify them. In addition to other classification methods, cluster analysis has begun to be used. This method produces a certain number of clusters, with objects in one cluster having similar properties, and objects in different clusters having as many different properties as possible.

The input for cluster analysis is represented by $N$ objects denoted by indexes $1<i<N$, which have $d$ features indexed as $1<j<d$. These data are used to write to the $N \times d$ matrix:

$$
X=\left(\begin{array}{cccc}
x_{11} & x_{12} & \ldots & x_{1 d} \\
x_{21} & x_{22} & \ldots & x_{2 d} \\
\vdots & \vdots & \ddots & \vdots \\
x_{N 1} & x_{N 2} & \ldots & x_{N d}
\end{array}\right)
$$

Line $d$-dimensional vector $\mathrm{x}_{\mathrm{i}}$ is a vector of the $i$-th object, while element $\mathrm{x}_{\mathrm{ij}}$ denotes the value of the $j$-th feature of the $i$-th object.

The cluster analysis is comprised of four general steps. 1. Selecting and extracting the features, 2. Selecting the algorithm, 3. Verifying accuracy, 4. Evaluating the results.

The IBM SPSS Statistics 22 programme was used to conduct the clustering. As a result of clustering, based on the values of the index of pro-Europeanness, five groups of districts with internal similarity were generated. 


\section{Analysis, results and findings}

\subsection{Levels of Territorial Units}

\subsubsection{Regions}

At the regional level, we analysed 22 spatial units, 14 regions in Czechia and eight regions in Slovakia (Fig. 1). These units also represent the NUTS 3 level. Their territorial and population size is markedly different, as the smallest region has an area of only $496.10 \mathrm{~km}^{2}$ (the city of Prague as a separate NUTS 3 region) while the largest has an area of $11,014.97 \mathrm{~km}^{2}$ (Central Bohemia Region). In Slovakia, the smallest region is the Bratislava Region $\left(2,052.5 \mathrm{~km}^{2}\right)$, and the largest is the Banská Bystrica Region $\left(9,454.4 \mathrm{~km}^{2}\right)$. In terms of population, the city of Prague is the smallest region in terms of area, but it has largest population $(1,301,135$ inhabitants) in Czechia, while the Karlovy Vary Region has the smallest population (data as of December 31, 2018, 295,686 inhabitants). In Slovakia, the differences between regions are also smaller in this indicator, as the region with highest number of inhabitants with permanent residence is the Prešov Region $(825,022)$, and the region with the lowest number of inhabitants is the Trnava Region $(563,591$ as of December 31, 2018). The areas with the greatest population density are the city of Prague $(2,622$ inhabitants $/ \mathrm{km}^{2}$ ) in Czechia and the Bratislava Region (321 inhabitants $/ \mathrm{km}^{2}$ ) in Slovakia. On the contrary, the South Bohemian Region (63 inhabitants $/ \mathrm{km}^{2}$ ) and the Banská Bystrica Region (68 inhabitants $/ \mathrm{km}^{2}$ ) are the least inhabited areas.

\subsubsection{Districts}

At the district level, we worked with 149 units, 77 in Czechia and 72 in Slovakia (Fig. 2, Tab. 1). In the case of Slovakia, the municipal districts of Bratislava (5) and Košice (4) were connected to one district in the entire city in order to strengthen the comparative value of the analysis with the other districts of the countries. The largest district in Czechia is the district of Klatovy in the Plzeň Region, with an area of $1,945.69 \mathrm{~km}^{2}$, while the Levice district in the Nitra Region $\left(1,551.1 \mathrm{~km}^{2}\right)$ is the largest in Slovakia. On the other hand, the Brno-město district $\left(230.22 \mathrm{~km}^{2}\right)$ is the smallest in Czechia and the Kysucké Nové Mesto district $\left(173.7 \mathrm{~km}^{2}\right)$ is the smallest in Slovakia. In Czechia, the city of Prague has the largest population (1,301,135 inhabitants); on the contrary, the Jeseník district in the Olomouc Region has the smallest population (38,330 inhabitants as of December 31,2018$)$. The most populous area in Slovakia is the city of Bratislava (432,864 inhabitants), while the Medzilaborce district in the Prešov region is the least populous $(11,896$ inhabitants as of December 31,2018 ). In terms of population density, Prague $\left(2,622\right.$ inhabitants $\left./ \mathrm{km}^{2}\right)$ dominates in Czechia, while the Prachatice district in the South Bohemian Region (37 inhabitants $/ \mathrm{km}^{2}$ ) is the least populated. In Slovakia, Bratislava $\left(1,177\right.$ inhabitants $\left./ \mathrm{km}^{2}\right)$ has the

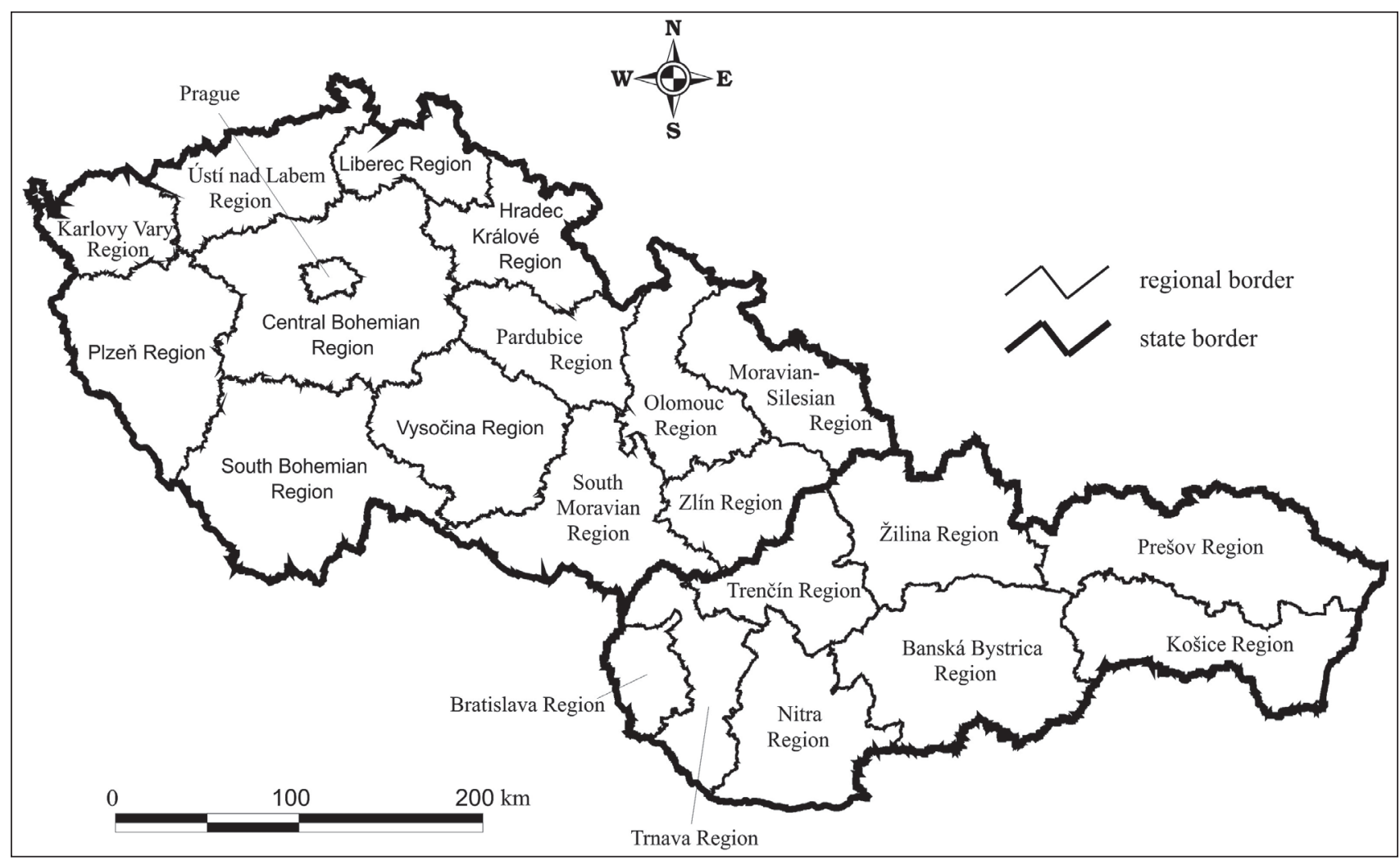

Fig. 1 Territorial composition of NUTS 3 regions in Czechia and Slovakia.

Source: Czech Statistical Office, Statistical Office of the Slovak Republic (2019). 


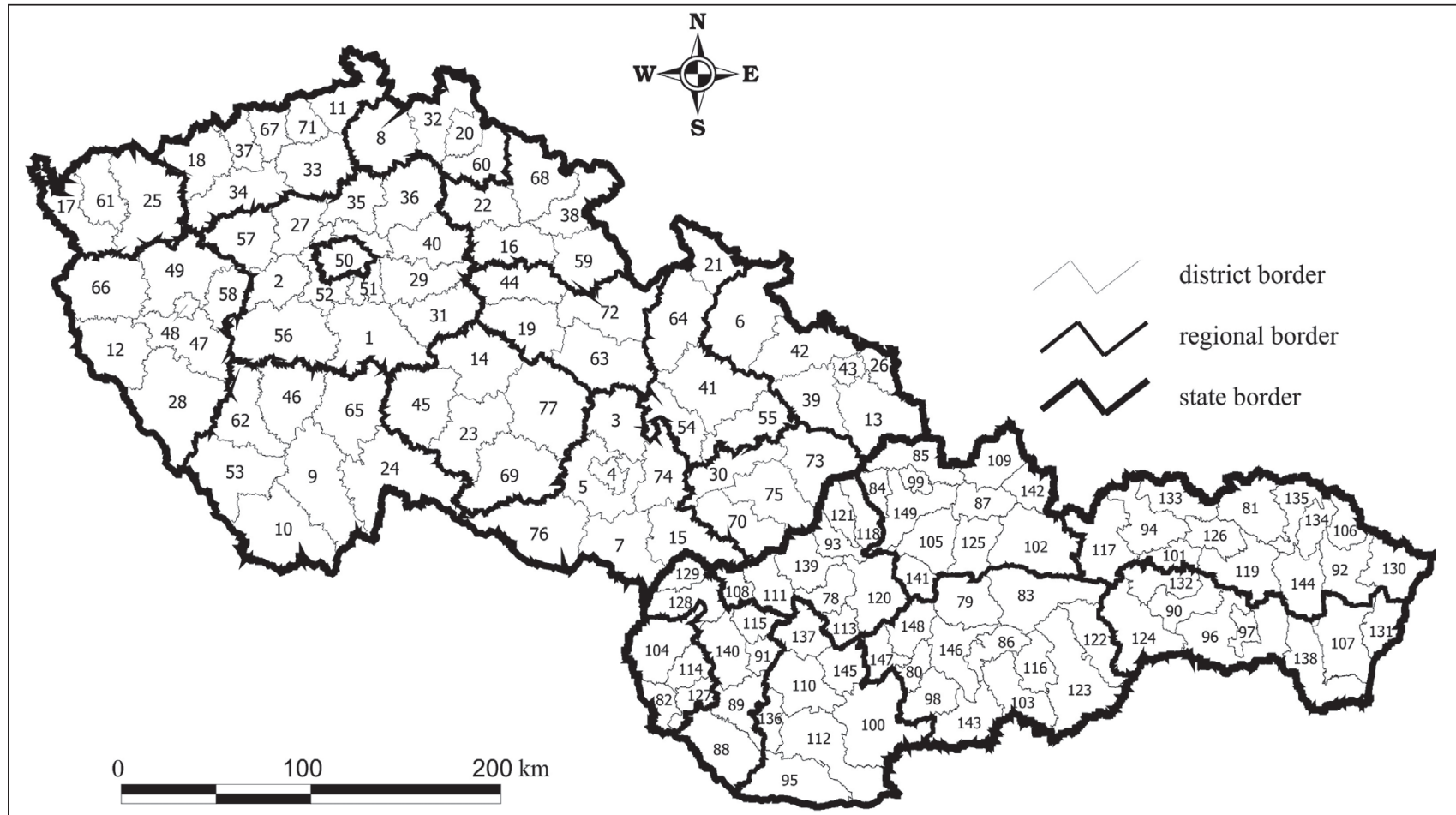

Fig. 2 Territorial composition of districts in Czechia and Slovakia.

Source: Czech Statistical Office, Statistical Office of the Slovak Republic (2019).

Tab. 1 Order number of districts in Czechia and Slovakia.

\begin{tabular}{|c|l|l|l|}
$\begin{array}{c}\text { Order } \\
\text { Number }\end{array}$ & District & Region & Country \\
\hline 1 & Benešov & Central Bohemian Region & Czechia \\
\hline 2 & Beroun & Central Bohemian Region & Czechia \\
\hline 3 & Blansko & South Moravian Region & Czechia \\
\hline 4 & Brno-město & South Moravian Region & Czechia \\
\hline 5 & Brno-venkov & South Moravian Region & Czechia \\
\hline 6 & Bruntál & Moravian-Silesian Region & Czechia \\
\hline 7 & Břeclav & South Moravian Region & Czechia \\
\hline 8 & Česká Lípa & Liberec Region & Czechia \\
\hline 9 & České Budějovice & South Bohemian Region & Czechia \\
\hline 10 & Český Krumlov & South Bohemian Region & Czechia \\
\hline 11 & Děčin & Ústí nad Labem Region & Czechia \\
\hline 12 & Domažlice & Plzeň Region & Czechia \\
\hline 13 & Frýdek-Místek & Moravian-Silesian Region & Czechia \\
\hline 14 & Havlíč́v Brod & Vysočina Region & Czechia \\
\hline 15 & Hodonín & South Moravian Region & Czechia \\
\hline 16 & Hradec Králové & Hradec Králové Region & Czechia \\
\hline 17 & Cheb & Karlovy Vary Region & Czechia \\
\hline 18 & Chomutov & Ústí nad Labem Region & Czechia \\
\hline 19 & Chrudim & Pardubice Region & Czechia \\
\hline 20 & Jablonec nad Nisou & Liberec Region & Czechia \\
\hline 21 & Jeseník & Olomouc Region & Czechia \\
\hline 22 & Jičín & Hradec Králové Region & Czechia \\
\hline 23 & Jihlava & Vysočina Region & Czechia \\
\hline 24 & Jindřichův Hradec & South Bohemian Region & Czechia \\
\hline 25 & Karlovy Vary & Karlovy Vary Region & Czechia \\
\hline & & & \\
\hline
\end{tabular}

\begin{tabular}{|c|l|l|l|}
$\begin{array}{c}\text { Order } \\
\text { Number }\end{array}$ & District & Region & Country \\
\hline 26 & Karviná & Moravian-Silesian Region & Czechia \\
\hline 27 & Kladno & Central Bohemian Region & Czechia \\
\hline 28 & Klatovy & Plzeň Region & Czechia \\
\hline 29 & Kolín & Central Bohemian Region & Czechia \\
\hline 30 & Kroměříz & Zlín Region & Czechia \\
\hline 31 & Kutná Hora & Central Bohemian Region & Czechia \\
\hline 32 & Liberec & Liberec Region & Czechia \\
\hline 33 & Litoměrice & Ústínad Labem Region & Czechia \\
\hline 34 & Louny & Ústí nad Labem Region & Czechia \\
\hline 35 & Mělník & Central Bohemian Region & Czechia \\
\hline 36 & Mladá Boleslav & Central Bohemian Region & Czechia \\
\hline 37 & Most & Ústínad Labem Region & Czechia \\
\hline 38 & Náchod & Hradec Králové Region & Czechia \\
\hline 39 & Nový Jičín & Moravian-Silesian Region & Czechia \\
\hline 40 & Nymburk & Central Bohemian Region & Czechia \\
\hline 41 & Olomouc & Olomouc Region & Czechia \\
\hline 42 & Opava & Moravian-Silesian Region & Czechia \\
\hline 43 & Ostrava-město & Moravian-Silesian Region & Czechia \\
\hline 44 & Pardubice & Pardubice Region & Czechia \\
\hline 45 & Pelhřimov & Vysočina Region & Czechia \\
\hline 46 & Písek & South Bohemian Region & Czechia \\
\hline 47 & Plzeň-jih & Plzeň Region & Czechia \\
\hline 48 & Plzeň-město & Plzeň Region & Czechia \\
\hline 49 & Plzeň-sever & Plzeň Region & Czechia \\
\hline 50 & Praha* & Prague & Czechia \\
\hline 51 & Praha-východ & Central Bohemian Region & Czechia \\
\hline & & & \\
\hline
\end{tabular}




\begin{tabular}{|c|c|c|c|}
\hline $\begin{array}{c}\text { Order } \\
\text { Number }\end{array}$ & District & Region & Country \\
\hline 52 & Praha-západ & Central Bohemian Region & Czechia \\
\hline 53 & Prachatice & South Bohemian Region & Czechia \\
\hline 54 & Prostějov & Olomouc Region & Czechia \\
\hline 55 & Přerov & Olomouc Region & Czechia \\
\hline 56 & Př́bram & Central Bohemian Region & Czechia \\
\hline 57 & Rakovník & Central Bohemian Region & Czechia \\
\hline 58 & Rokycany & Plzeň Region & Czechia \\
\hline 59 & $\begin{array}{l}\text { Rychnov nad } \\
\text { Kněžnou }\end{array}$ & Hradec Králové Region & Czechia \\
\hline 60 & Semily & Liberec Region & Czechia \\
\hline 61 & Sokolov & Karlovy Vary Region & Czechia \\
\hline 62 & Strakonice & South Bohemian Region & Czechia \\
\hline 63 & Svitavy & Pardubice Region & Czechia \\
\hline 64 & Šumperk & Olomouc Region & Czechia \\
\hline 65 & Tábor & South Bohemian Region & Czechia \\
\hline 66 & Tachov & Plzeň Region & Czechia \\
\hline 67 & Teplice & Ústí nad Labem Region & Czechia \\
\hline 68 & Trutnov & Hradec Králové Region & Czechia \\
\hline 69 & Třebíč & Vysočina Region & Czechia \\
\hline 70 & Uherské Hradiště & Zlín Region & Czechia \\
\hline 71 & Ústí nad Labem & Ústí nad Labem Region & Czechia \\
\hline 72 & Ústí nad Orlicí & Pardubice Region & Czechia \\
\hline 73 & Vsetín & Zlín Region & Czechia \\
\hline 74 & Vyškov & South Moravian Region & Czechia \\
\hline 75 & Zlín & Zlín Region & Czechia \\
\hline 76 & Znojmo & South Moravian Region & Czechia \\
\hline 77 & Žd'ár nad Sázavou & Vysočina Region & Czechia \\
\hline 78 & $\begin{array}{l}\text { Bánovce nad } \\
\text { Bebravou }\end{array}$ & Trenčín Region & Slovakia \\
\hline 79 & Banská Bystrica & Banská Bystrica Region & Slovakia \\
\hline 80 & Banská Štiavnica & Banská Bystrica Region & Slovakia \\
\hline 81 & Bardejov & Prešov Region & Slovakia \\
\hline 82 & Bratislava* & Bratislava Region & Slovakia \\
\hline 83 & Brezno & Banská Bystrica Region & Slovakia \\
\hline 84 & Bytča & Žilina Region & Slovakia \\
\hline 85 & Čadca & Žilina Region & Slovakia \\
\hline 86 & Detva & Banská Bystrica Region & Slovakia \\
\hline 87 & Dolný Kubín & Žilina Region & Slovakia \\
\hline 88 & Dunajská Streda & Trnava Region & Slovakia \\
\hline 89 & Galanta & Trnava Region & Slovakia \\
\hline 90 & Gelnica & Košice Region & Slovakia \\
\hline 91 & Hlohovec & Trnava Region & Slovakia \\
\hline 92 & Humenné & Prešov Region & Slovakia \\
\hline 93 & Ilava & Trenčín Region & Slovakia \\
\hline 94 & Kežmarok & Prešov Region & Slovakia \\
\hline 95 & Komárno & Nitra Region & Slovakia \\
\hline 96 & Košice - okolie & Košice Region & Slovakia \\
\hline 97 & Košice* & Košice Region & Slovakia \\
\hline 98 & Krupina & Banská Bystrica Region & Slovakia \\
\hline 99 & Kysucké Nové Mesto & Žilina Region & Slovakia \\
\hline 100 & Levice & Nitra Region & Slovakia \\
\hline 101 & Levoča & Prešov Region & Slovakia \\
\hline
\end{tabular}

\begin{tabular}{|c|c|c|c|}
\hline $\begin{array}{c}\text { Order } \\
\text { Number }\end{array}$ & District & Region & Country \\
\hline 102 & Liptovský Mikuláš & Žilina Region & Slovakia \\
\hline 103 & Lučenec & Banská Bystrica Region & Slovakia \\
\hline 104 & Malacky & Bratislava Region & Slovakia \\
\hline 105 & Martin & Žilina Region & Slovakia \\
\hline 106 & Medzilaborce & Prešov Region & Slovakia \\
\hline 107 & Michalovce & Košice Region & Slovakia \\
\hline 108 & Myjava & Trenčín Region & Slovakia \\
\hline 109 & Námestovo & Žilina Region & Slovakia \\
\hline 110 & Nitra & Nitra Region & Slovakia \\
\hline 111 & $\begin{array}{l}\text { Nové Mesto } \\
\text { nad Váhom }\end{array}$ & Trenčín Region & Slovakia \\
\hline 112 & Nové Zámky & Nitra Region & Slovakia \\
\hline 113 & Partizánske & Trenčín Region & Slovakia \\
\hline 114 & Pezinok & Bratislava Region & Slovakia \\
\hline 115 & Pieštany & Trnava Region & Slovakia \\
\hline 116 & Poltár & Banská Bystrica Region & Slovakia \\
\hline 117 & Poprad & Prešov Region & Slovakia \\
\hline 118 & Považská Bystrica & Trenčín Region & Slovakia \\
\hline 119 & Prešov & Prešov Region & Slovakia \\
\hline 120 & Prievidza & Trenčín Region & Slovakia \\
\hline 121 & Púchov & Trenčín Region & Slovakia \\
\hline 122 & Revúca & Banská Bystrica Region & Slovakia \\
\hline 123 & Rimavská Sobota & Banská Bystrica Region & Slovakia \\
\hline 124 & Rožňava & Košice Region & Slovakia \\
\hline 125 & Ružomberok & Žilina Region & Slovakia \\
\hline 126 & Sabinov & Prešov Region & Slovakia \\
\hline 127 & Senec & Bratislava Region & Slovakia \\
\hline 128 & Senica & Trnava Region & Slovakia \\
\hline 129 & Skalica & Trnava Region & Slovakia \\
\hline 130 & Snina & Prešov Region & Slovakia \\
\hline 131 & Sobrance & Košice Region & Slovakia \\
\hline 132 & Spišská Nová Ves & Košice Region & Slovakia \\
\hline 133 & Stará Ĺubovňa & Prešov Region & Slovakia \\
\hline 134 & Stropkov & Prešov Region & Slovakia \\
\hline 135 & Svidník & Prešov Region & Slovakia \\
\hline 136 & Šal'a & Nitra Region & Slovakia \\
\hline 137 & Topol'čany & Nitra Region & Slovakia \\
\hline 138 & Trebišov & Košice Region & Slovakia \\
\hline 139 & Trenčín & Trenčín Region & Slovakia \\
\hline 140 & Trnava & Trnava Region & Slovakia \\
\hline 141 & Turčianske Teplice & Žilina Region & Slovakia \\
\hline 142 & Tvrdošín & Žilina Region & Slovakia \\
\hline 143 & Vel'ký Krtíš & Banská Bystrica Region & Slovakia \\
\hline 144 & Vranov nad Topl'ou & Prešov Region & Slovakia \\
\hline 145 & Zlaté Moravce & Nitra Region & Slovakia \\
\hline 146 & Zvolen & Banská Bystrica Region & Slovakia \\
\hline 147 & Žarnovica & Banská Bystrica Region & Slovakia \\
\hline 148 & Žiar nad Hronom & Banská Bystrica Region & Slovakia \\
\hline 149 & Žilina & Žilina Region & Slovakia \\
\hline
\end{tabular}

Notes: * whole city as a one district for this purpose

Source: Czech Statististical Office, Statistical Office of the Slovak Republic (2019). 
highest population density, while the Medzilaborce district (27 inhabitants $/ \mathrm{km}^{2}$ ) has the lowest population density.

\subsection{Results and Findings}

\subsubsection{Regions}

\section{Pro-Europeanness Index}

At the regional level (Fig. 3), the highest pro-Europeanness index values (ranging from 0.700 to 0.906 ) reflecting five variables in total (votes for accession in the 2003 European Union membership referendum, votes for Eurosceptic parties in the 2004-2019 European Parliament elections) were recorded by Bratislava followed by other four regions from Slovakia (Trnava, Nitra, Košice and Prešov). A level of 0.700 was almost achieved also by the capital region of Czechia, Prague. Other two regions from Slovakia (Banská Bystrica and Žilina) reached the values of index from 0.500 to 0.600 . The values between $0.400-0.500$ were obtained by two regions from Czechia (Zlín and South Moravia) and the last Slovak region, Trenčín. On the contrary, the lowest values of the index (0.029-0.294) were reported by the Ústí nad Labem Region, the Karlovy Vary Region and the Moravian-Silesian Region in Czechia. Of the last twelve regions, all are from Czechia.

Considering regional perspective, one of the highest spatial concentrations were recorded also in regions of Prague, Bratislava and Košice, i.e. centres that have been more successful in the post-socialist transformation, with higher economic performance, localization of significant foreign investment, a population with higher education and socio-economic status, supporting, in general, liberal political parties.
Highest values also applied to regions using EU agricultural subsidies and promoting a policy of guaranteeing the rights of ethnic minorities (especially the Trnava Region and the Nitra Region in Slovakia), or typical of an approach toward the values of Christian Democracy (the Zlín Region in Czechia and the Prešov Region in Slovakia). On the contrary, the lowest values were recorded in the Czech regions with a peripheral position geographically and socio-economically (Ústí nad Labem Region and Karlovy Vary Region), with increased support for the far-left or farright parties and the Slovak region with a traditionally egalitarian, etatist and nationalist electorate (Trenčín Region).

\subsubsection{Districts}

We came up with other interesting findings for the pro-Europeanness index at the district level.

\section{Pro-Europeanness Index}

The resulting index shows considerable spatial differences (Fig. 4). In the districts with the highest values of the index, the Slovakian districts absolutely dominate, with the first being Dunajská Streda (0.994) and second Komárno (0.903). Other districts with high values of index are located exclusively in the southwest of Slovakia. These districts, with geographical proximity to the capital, enjoy a significant position in the agro-sector and a strong Hungarian minority. In the case of Czechia, the highest values were reached by districts of Prague (Praha-západ, Praha and Praha-východ) and the city district of the second largest city of the country, Brno (Brno-město). On the contrary, districts with the lowest values (below 0.200) are located in west Bohemia in the Ústí nad

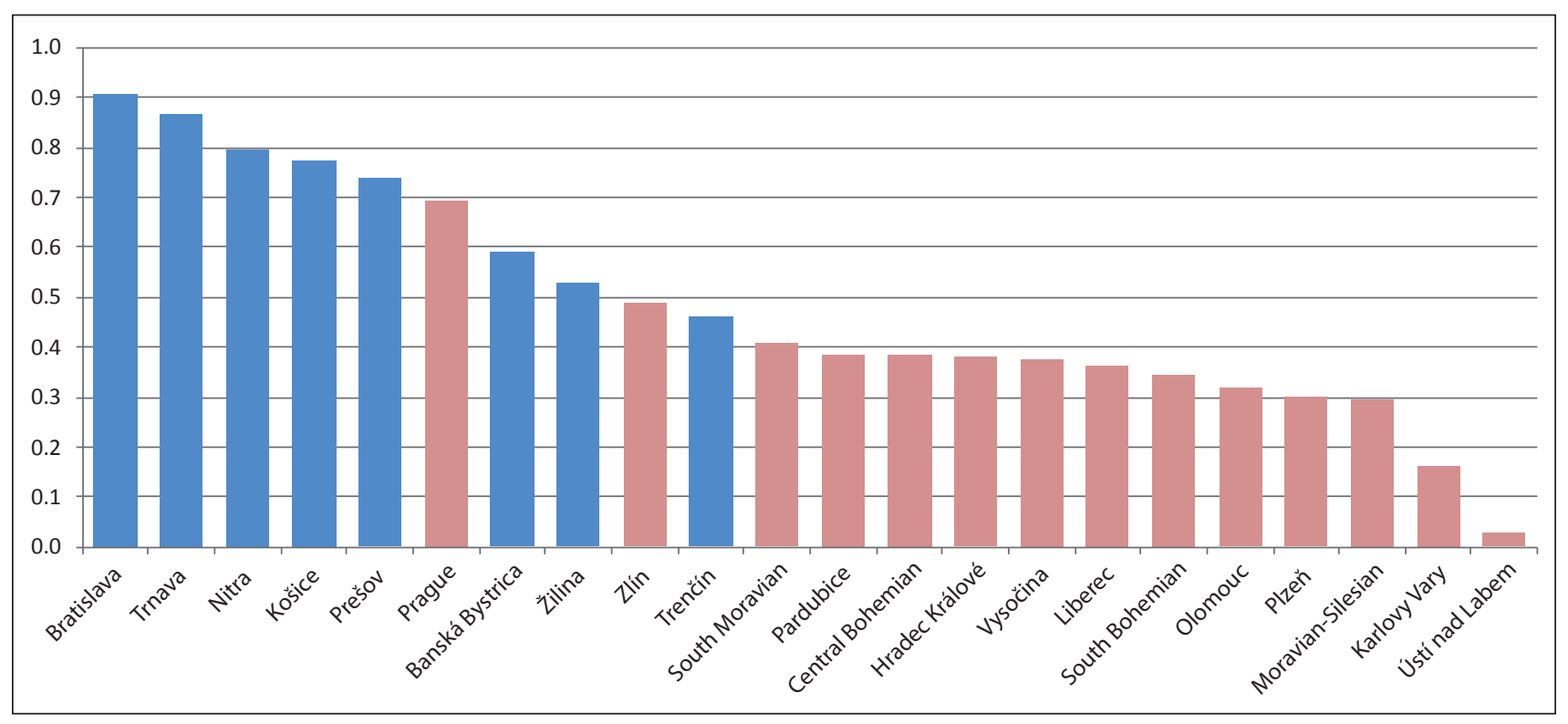

Fig. 3 NUTS 3 regions of Czechia and Slovakia by Index of Pro-Europeaness.

Note: Light greyindicates the Czech regions, dark gray indicates the Slovak regions.

Source: Czech Statistical Office, Statistical Office of the Slovak Republic (2019), author's research. 


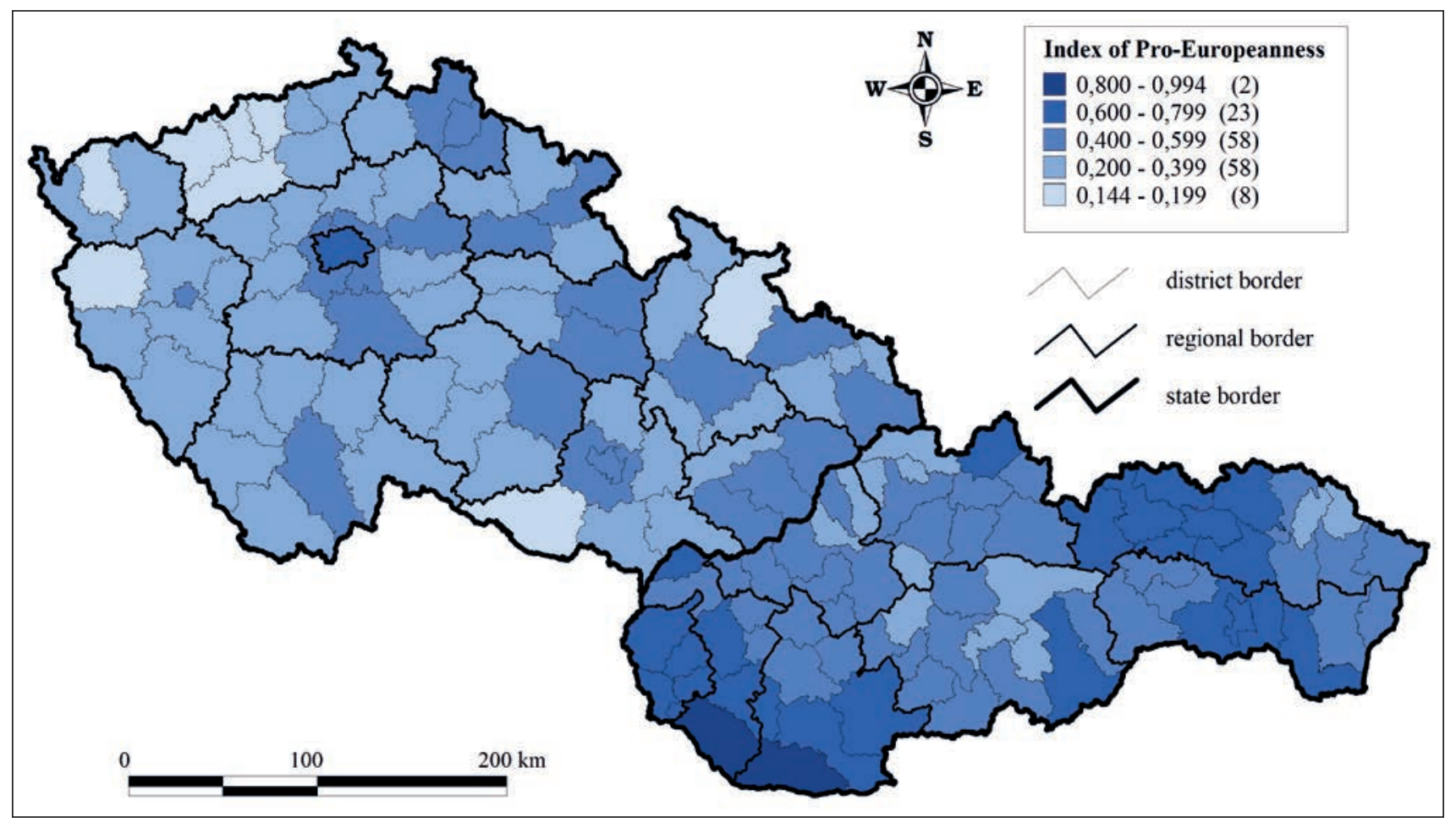

Fig. 4 Districts of Czechia and Slovakia by Index of Pro-Europeaness.

Source: Czech Statistical Office, Statistical Office of the Slovak Republic (2018), author's research.

Labem Region (Most 0.144, Louny 0.156, Chomutov 0.164 and Teplice 0.171), the Plzen Region (Tachov 0.161 ) and the Karlovy Vary Region (Sokolov 0.190). This group of districts is completed by couple from Moravia - Bruntál (0.151, Moravian-Silesian Region) and Znojmo (0.168, South Moravian Region). This group of districts is characterized by a relatively high unemployment rate and relatively low wages, with support for left-wing, far-left or far-right parties (Havlík and Voda 2016; Maškarinec 2017, 2019). In Slovakia, the districts with the lowest values are located in the northwestern corner of the country in the Žilina Region (Kysucké Nové Mesto, Čadca and Bytča) typical of long-term support for the values of egalitarianism, etatism and nationalism (Plešivčák 2011; Madleňák 2012).

\subsubsection{Clusters}

By using the cluster method, we derived five categories based on the values of the pro-Europeanness index (Fig. 5).

The first category, named "districts of markedly pro-European orientation", consists of only two spatial units, both located in Slovakia. The districts belonging to this cluster are located in southwest Slovakia (Dunajska Streda and Komárno), with a traditional position of agriculture and a strong Hungarian minority. Compared to the national mean (Fig. 6), this group recorded strong support for country's accession to the EU $(+14.06 p p)$ and very low support for Eurosceptic parties $(-16.92 p p)$.
The second cluster, named "districts of significantly pro-European orientation" is comprised of 19 districts, of which all are located in Slovakia again. The largest concentration of these districts can be found in the area located in the southwest corner of the country (Bratislava, Šal'a, Galanta, Senec, Nové Zámky) and in the Prešov Region in the northeast (a compact belt of the six districts - Poprad, Kežmarok, Levoča, Stará Lubovňa, Bardejov, Sabinov and Prešov) continuing to the Košice Region in the east of Slovakia (Košice and Trebišov). This cluster also includes three largest towns of Slovakia (Bratislava, Košice and Prešov). Compared to the national average (Fig. 6), this category declared a strong support for accession in the EU referendum $(+12.71 p p)$ and lower support for Eurosceptic parties in the EU elections (-7.99 pp).

The third category of districts is described as "districts of mildly pro-European orientation". It consists of 30 spatial units, the larger part of which (23) is located in Slovakia. The main concentration is recognized in the regions of Bratislava, Trnava and Nitra in the southwest of Slovakia with seven districts overall (Pezinok, Malacky, Trnava, Senica, Nitra, Piešt’any and Hlohovec). The second compact area can be identified in the north of the country in the eastern part of the Žilina Region (Dolný Kubín, Tvrdošín, Martin, Liptovský Mikuláš and Ružomberok). This concentration is comprehensively complemented by four adjacent districts, from the Banská Bystrica Region (Banská Bystrica, Zvolen, Vel'ký Krtíš and Lučenec). The third concentration of districts of this type is 


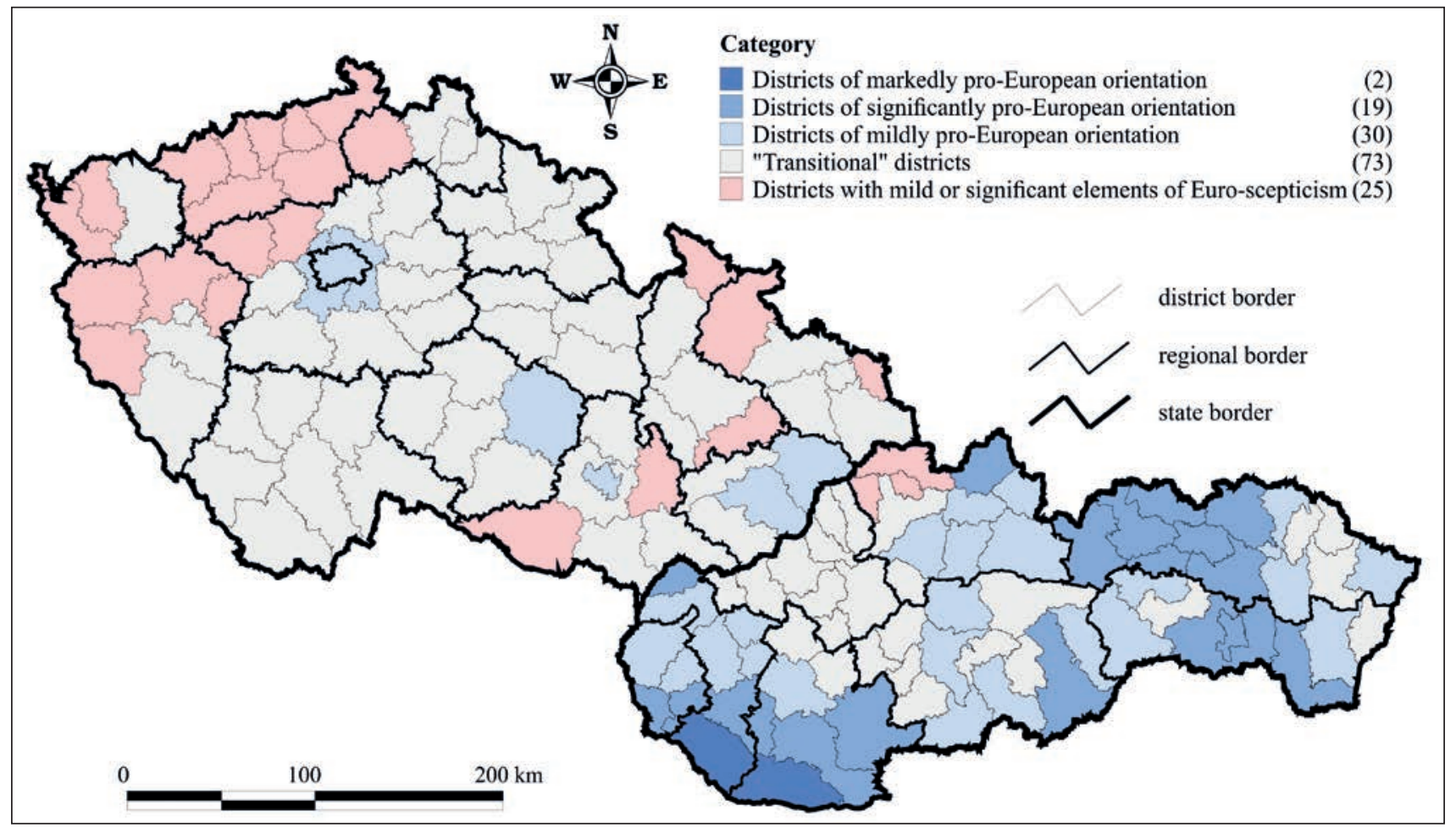

Fig. 5 Categories of districts in Czechia and Slovakia clustered by Index of Pro-Europeaness.

Source: Czech Statistical Office, Statistical Office of the Slovak Republic (2019), author's research.

located in the eastern part of Slovakia in the regions of Banská Bystrica (Revúca), Košice (Rožňava, Spišská Nová Ves and Mihcalovce) and Prešov (Snina, Vranov nad Toplou and Svidník). In Czechia, the only cluster of districts of mildly pro-European orientation can be found in the capital region (districts of Prague). One district is located in the east of the Vysočina Region (Ždár nad Sázavou), three in Moravia in South Moravian Region (Brno-město) and Zlín Region (Zlín, Vsetín). Two largest cities of Czechia (Prague and Brno) fell into this category. This group is characterized by (Fig. 6) slightly above-average support for EU accession $(+2.44 p p)$ and lower support for the Eurosceptic parties in EU elections ( $-4.06 \mathrm{pp}$ ).

The fourth group of districts, which is the most numerous of all clusters, we labelled "transitional" districts. Cluster analysis marked 73 spatial units (almost a half of all districts), of which 48 (66\%) are located in Czechia. The largest concentration of districts of this type can be identified in the central and eastern Bohemia. In Slovakia, the most compact area is situated in all territory of Trenčín Region and adjacent districts. This category of districts is characterized by (Fig. 6) slightly below average support for EU accession $(-3.51 p p)$ and mildly higher support for Eurosceptic parties in EU elections (+2.15 pp).

The last group consists of districts characterized by the notable degree of Euroscepticism ("districts with mild or significant elements of Euroscepticism"). of the total number of 149 districts, 25 fall into this category, with 22 (88\%) from Czechia. Most are located in the Ústí nad Labem Region (7 of 7), the Plzeň Region (4 of 7) and the Moravian-Silesian Region (3 of 7). Most of them, mainly from the Ústí nad Labem Region and the Moravian-Silesian Region, have certain socio-economic problems (relatively high unemployment, and low wages), favouring left-wing, far-left and recently protest parties to some extent. The most visible concentration is located in the northwest of Czechia, encompassing the regions of Liberec (Česká Lípa), Ústí nad Labem (Děčín, Ústí nad Labem, Teplice, Litoměřice, Most, Louny and Chomutov), Central Bohemia (Rakovník and Kladno), Karlovy Vary (Sokolov and Cheb) and Plzeň (Domažlice, Tachov, Plzeň-sever and Rokycany). In the historical regions of Moravia and Silesia, there are six such districts, namely Znojmo, Vyškov (South Moravian Region), Přerov (Olomouc Region), Jeseník, Bruntál and Karviná (Moravian-Silesian Region). Within Slovakia, districts of this type are located exclusively in the northwest of the territory in the Žilina Region (Bytča, Čadca, Kysucké Nové Mesto), where they formed a compact concentration. This area is known for its traditional support of nationalist parties, and the values of etatism and egalitarianism. Compared to the national average (Fig. 6), this cluster of districts is characterized by a markedly below average approval for EU accession $(-6.44 p p)$ and an outstanding support for the Eurosceptic parties in EU elections $(+8.25 p p)$. 


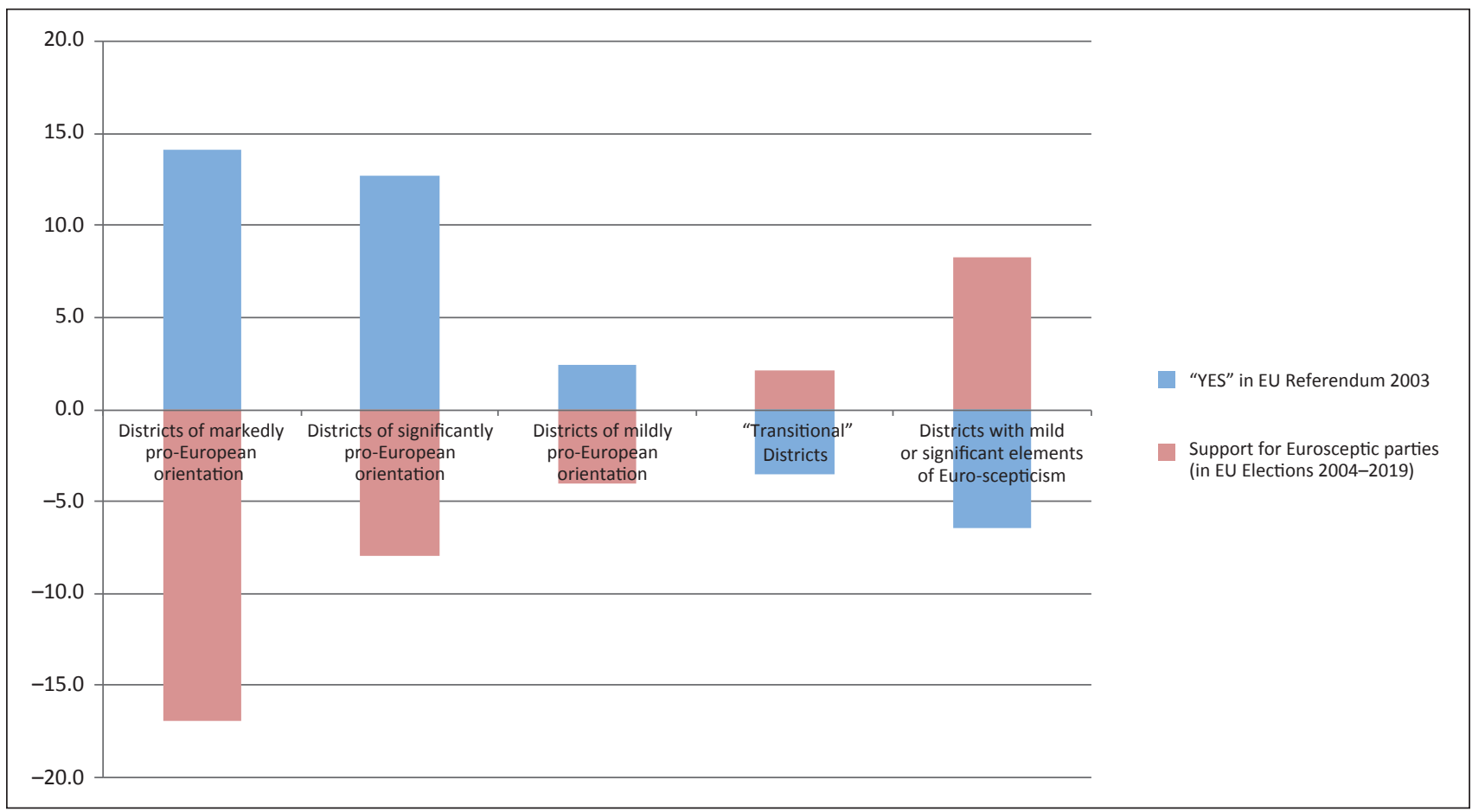

Fig. 6 Categories of districts in Czechia and Slovakia clustered by Index of Pro-Europeaness - selected EU electoral characteristics. Note: Difference from average value for Czechia and Slovakia, difference is measured by percentage points. Source: Czech Statistical Office, Statistical Office of the Slovak Republic (2019), author's research.

\section{Discussion}

Some regions of Czechia and Slovakia are characterized by increased turnout and low level of Euroscepticism in the case of European issues (referendum, elections), while others are more passive in voting or support Eurosceptic parties to a great extent. The most frequent reasons for not participating in European parliamentary elections include disappointment with politics, non-alignment with the electoral program of any of the parties, and a lack of political commitment as such (Greffet 2007). In the debate on interest in voting in European elections as well as support for Eurosceptics, it is also important to mention the voter's relationship to the idea of Euro-citizenship (Frognier 2000), the project of European integration, Europeanism, the degree of awareness related to the role of the EU and the benefits of membership (Blondel et al. 1997) and the visibility of the EU in ordinary life (Irwin 1995). Voters of regions benefiting more from EU membership, e.g. through structural funds, have a higher tendency to participate in the European Parliament elections and support Euro-optimist parties (Jesuit 2003). In the case of Czechia, reasons for voter (non)participation were investigated by Linek (2013), in Slovakia by Gyárfášová (2019).

It turns out that the current wave of Euroscepticism or populism is better understood by the far-right subjects (in Czechia in particular by SPD and in Slovakia by LSNS). They are able to attract manual workers who previously almost unreservedly supported the left (Bale 2010). Nevertheless, in Czechia, the far-left KSČM has been enjoying significant support in the case of elections to the European Parliament, though currently of declining trend. Economic problems and migratory pressures are causing uncertainty in Europe and create a breeding ground for populists (Charvát 2007). Quite a number of authors have recently addressed the causes of support for far-right parties in Czechia and Slovakia (e.g. Kluknavská 2012, 2013; Gregor 2015; Mikuš et al. 2016). In general, increase in Euroscepticism can be linked to ongoing globalization (Salo 2014). It has created a group of "bereaved" who are losing certainty and feeling vulnerable to the current liberalization, worrying about their economic future and growing cultural diversity. Eurosceptics does not necessarily have to be a result of populism, but also as a legitimate part of the political arena that represents those "bereaved" by globalization (Salo 2014). It is said about the new European cleavage of social polarization based on the existence of various life and material opportunities (in our research, especially socio-economic status, civil and minority rights) perceived by different actors with different interests depending on the process of territorial integration (Bartolini 2007).

\section{Conclusions}

Considering the NUTS 3 regions of both countries (14 in Czechia and 8 in Slovakia) in terms of the final index 
of pro-Europeanness and regional cleavage, the highest values were achieved by the regions of the largest cities (Prague in the Czechia, Bratislava and Košice in Slovakia) typical of a more educated, urban population with a higher socio-economic status, more economically efficient and more successful in post-socialist transformation, with a higher concentration of large, especially foreign investment, and a predominant right-wing (or central/liberal) electorate. The second case of a pronounced tendency towards the EU project is represented by regions using EU subsidies under its largest agricultural policy, also dependent on the supranational policy securing the rights of ethnic minorities (especially the Trnava Region and the Nitra Region in Slovakia) or known for values of Christian Democracy (the Zlín Region in Czechia and the Prešov Region in Slovakia). On the contrary, the lowest values of the pro-Europeanness index were registered in the socio-economically and geographically peripheral regions of Czechia, with increased support for far-left, far-right and protest parties (the Ústí nad Labem Region, the Karlovy Vary Region and the Moravian-Silesian Region) and parts of Slovakia with a population traditionally close to the values of egalitarian, etatism and nationalism (the Trenčín Region).

At the district level (149 districts in total, 77 from Czechia and 72 from Slovakia), it was found that in the top two categories ("districts of markedly pro-European orientation" and ("districts of significantly pro-European orientation"), with the highest values of the index of pro-Europeanness, the Slovak districts (mainly from the southwest) dominated over Czech districts. On the contrary, $88 \%$ districts of the last category ("districts with mild or significant elements of Euroscepticism") came from Czechia, with the absolute lowest values being registered for districts from Ústí nad Labem Region (northwestern Bohemia).

By using the cluster method, we derived five categories of districts across the countries based on the values of the pro-Europeanness index. The first three "evidently pro-European" groups ("districts of markedly, significantly or mildly pro-European orientation") consists of 51 spatial units, $86 \%$ of them located in Slovakia. The districts of these clusters are characterized by a clear support for accession to the European Union and low support for Eurosceptic parties in European Parliament elections. Several districts of this type are urban (districts of Prague, Brno-město in Czechia, and Bratislava, Košice and Prešov in Slovakia), while others are located in southwest Slovakia (Senec, Dunajska Streda, Komárno and Nové Zámky) where there is relatively significant agricultural production and a strong concentration of the Hungarian minority. On the opposite side, there are districts with mild or significant elements of Euroscepticism, with significantly lower support for EU accession relevant support for Eurosceptic parties when EU elections take place. Of the 25 spatial units in this category, 22 are from the Czechia. The highest concentration was found mainly in the Ústí nad Labem Region, the Karlovy Vary Region and the Moravian-Silesian Region, i.e. in regions with relatively significant socio-economic difficulties (relatively high unemployment and low wages), with increasing support for radical (leftwing or right-wing) and protest (anti-system) parties. Within Slovakia, districts of this type are located in the northwest of the territory in the Žilina Region (Bytča, Čadca, Kysucké Nové Mesto), which traditionally support nationalist parties and espouse values of etatism and egalitarianism.

In general, ideas of European integration and Euro-optimism as such in Czechia and Slovakia are more common among the urban electorates (Prague, Brno, Bratislava, Košice), areas with a higher concentration of a particular ethnic group, with significant agricultural production (southwest of Slovakia), which in this case is probably related to the status of the EU as a guarantor (higher instance for protection) of civil and minority rights, and a provider of agro-subsidies. In the case of Euroscepticism, the Czech districts and regions prevail, especially from the peripheral northwest and the Moravian-Silesian border areas. In this context, relatively important socio-economic problems (in comparison with the national average high unemployment and low wages) can be mentioned. Part of the electorate can "blame" the EU (membership) for them (or at least in the form of a penalty for their failure to solve them) and thus, on a practical level, can prefer populist (radical, anti-system) and Eurosceptic parties. In the case of Slovakia, regions located to the northwest without significant socio-economic problems, but with the traditional vote for (ultra)nationalists (LSNS, formerly voting for SNS), egalitarian and etatist-minded political movements (SMER-SD, formerly voting for HZDS), were shown as least pro-European oriented. The obtained results are in accordance with the findings of previous studies from the Czech (Pink 2012; Voda 2015; Kostelecký et al. 2016; Koubek 2019) and Slovak literature (e.g. Krivý et al. 1996; Plešivčák 2011; Madleňák 2012; Przybyla 2019) on the historical and socio-economic causes affecting the spatial distribution of election results.

This study provides new insights into the "geography of pro-Europeanness" over a relatively long period of time (2003-2019), at the sub-national level of regions and districts of two countries that in the past formed a single state, applying a methodology not used before to assess the territorial context of EU integration support. This work also provides information for policy- and decision-makers on the regions in which EU assistance should be targeted to sustain (restore) the meaningfulness of both the idea of European integration and EU membership in those parts of the countries that are currently most critical to the EU project, and thus to stop encouraging Euroscepticism across the EU, starting with its partial regions. 


\section{Acknowledgements}

This paper was prepared with the support provided by research grants of Slovak Research and Development Agency APVV-17-0079 "Population Analysis and Forecast of the Slovak Republic in Time-horizon 2080: Identification and Modelling the Impacts on Society in Different Spatial Scales".

\section{References}

Bale, T. (2010): If You Can't Beat Them Join Them? Explaining Social Democratic Responses to the Challenge from the Populist Radical Right in Western Europe. Political Studies 58(3), 410-426, https://doi.org /10.1111/j.1467-9248.2009.00783.x.

Bartolini, S. (2007): Cleavages. In: Encyclopaedia of European Elections. Ed. Y. Déloye, M. Bruter. Palgrave Macmillan, Basingstoke, 43-51.

Baun, M., Durr, J., Marek, D., Šaradín, P. (2006): The Europeanization of Czech Politics: The Political Parties and the EU Referendum. Journal of Common Market Studies 44(2), 249-280, https://doi.org/10.1111 /j.1468-5965.2006.00622.x.

Blondel, J., Sinnott, R., Svensson, P. (1997): Representation and Voter participation. European Journal for Political Research 32(2), 243-272, https://doi.org/10.1023 /A:1006832419724.

Blumer, J. G. (1983): Communicating to Voters. London, Sage.

Bradová, E., Šaradín, P. (2004): Volební kampaň. In: Volby do Evropského parlamentu v České republice. Ed. P. Šaradín. Periplum, Olomouc, 179-207.

Budge, I. (2001): Mapping Policy Preferences: Estimates for Parties, Electors and Governments (1945-1998). Oxford, Oxford University Press.

Cabada, L. (2010): Volby do Evropského parlamentu jako volby druhého řádu: reflexe voleb v nových členských zemích EU ze středovýchodní Evropy. Working Papers Fakulty mezinárodních vztahů 4(11), 5-26.

Carrubba, C., Timpone. R. (2005): Explaining vote switching across first-order and second order elections: evidence from Europe. Comparative Political Studies 38(3), 260-281, https://doi.org/10.1177 /0010414004272693.

Czech Statistical Office. (2019): Elections Database (2003-2019). Prague, Czech Statistical Office.

De Vries, C., van der Brug, W., van Egmond, M., van der Eijk, C. (2011): Individual and contextual variation in EU issue voting: The role of political information. Electoral Studies 30(1), 16-28, https://doi.org/10.1016 /j.electstud.2010.09.022.

Fiala, P., Hloušek, V., Pitrová, M., Pšeja, P. (2006): Evropeizace politických stran a zájmových skupin: základní problémy a směry analýzy. Politologický časopis 13(1), 3-26.

Frodnier, A.-P., (2000): Identité et participation électorale: pour une approche européenne des élections européennes. In: Le vote des Quinye. Les élections européennes du 13 juin 1999. Ed. G. Grunberg, P. Perrineau, C. Ysmal, C. Presses de Sciences, Paris, 75-94.
Goodwin, M. (2011): Right Response: Understanding and Countering Populist Extremism in Europe. London, Chatham House.

Greffet, F. (2007): Abstention. In: Encyclopaedia of European Election. Y. Déloye, M. Bruter. Palgrave Macmillan, Basingstoke, 1-6.

Gregor, K. (2015): Kto sú Kotlebovi voliči? Preskupovanie voličov v Banskobystrickom kraji v rokoch 2009 až 2014. Sociológia - Slovak Sociological Review 47(3), 235-252.

Gyárfášová, O. (2007): Jak volili Slováci ve volbách do EP v roce 2004 v kontextu veřejného vnímání Evropské unie. In: Volby do Evropského parlamentu 2004. L. Linek, J. Outlý, G. Tóka, A. Batory. Sociologický ústav AV ČR, Praha, 279-292.

Gyárfášová, O. (2019): Public's perception of the EU and turnout in the EP election. In: Euroflection. Eds. N. Bolin, K. Falasca, M. Grusell and L. Nord. Mittuniversitetet, Sundsvall, 56-56.

Gyárfášová, O. Velšic. M. (2004): Volebné správanie slovenských voličov v prvých eurovol'bách a širšie súvislosti vnímania členstva v EÚ. Bratislava, Inštitút pre verejné otázky.

Hastie, T., Tibshirani, R. Friedman, J. (2016): The Elements of Statistical Learning: Data Mining, Inference, and Prediction, Second Edition (Springer Series in Statistics). Berlin, Springer.

Havlík, V. (2008): Jak je měřit? Přístupy a metody analýzy postojů politických stran k evropské integraci. Central European Political Studies Review 10(4), 340-369.

Havlík, V. (2010): České politické strany a evropská integrace: Evropeizace, evropanství, euroskepticismus? Brno, Masarykova univerzita.

Havlík, V., Hoskovec, L. (2009): Krajské volby v České republice v kontextu konceptu voleb druhého řádu. Analýza vybraných aspektů voleb do krajských zastupitelstev v letech 2000-2008. European Electoral Studies 4(1), 22-47.

Havlík, V., Kaniok, P. (2006): Euroskepticismus a země střední a východní Evropy. Brno, Mezinárodní politologický ústav Masarykovy univerzity.

Havlík, V., Voda, P. (2016): The Rise of New Political Parties and Re-Alignment of Party Politics in the Czech Republic. Acta Politologica 8(2), 119-144.

Havlík, V., Vykoupilová, H. (2008): Two dimensions of the Europeanization of election programs: The case of the Czech Republic. Communist and Post-Communist Studies 41(2), 163-187, https://doi.org/10.1016 /j.postcomstud.2008.03.007.

Henderson, K. (2008): The Slovak Republic: Eurosceptics and Phoney Europhiles. In: The Party Politics of Euroscepticism, Vol. 1 Case Studies and Country Surveys. Eds. A. Szczerbiak and P. Taggart. Oxford University Press, Oxford, 277-294.

Hix, S., Marsh, M. (2007): Punishment or Protest? Understanding European Parliament Elections. The Journal of Politics 69(2), 495-510, https://doi. org//10.1111/j.1468-2508.2007.00546.x.

Hix, S., Marsh, M. (2011): Second-order effects plus panEuropean political swings: An analysis of European Parliament elections across time. Electoral Studies 30(1), 4-15, https://doi.org/10.1016/j.electstud.2010.09.017.

Hloušek, V., Pšeja, P. (2009): Europeanization of Political Parties and the Party System in the Czech Republic. Journal of Communist Studies and Transition Politics 
25(4), 513-539, https://doi.org/10.1080

/13523270903310902.

Hricová, H. (2009): Česká republika. In: Eurovolby 2009: Prostor pro evropeizaci politických stran ve středovýchdoní Evropě. L. Cabada, V. Hloušek. Aleš Čeněk, Plzeň, 41-66.

Hwang, C. L., Yoon, K. (1981): Multiple Attribute Decision Making: Methods and Applications. New York, SpringerVerlag, https://doi.org/10.1007/978-3-642-48318-9.

Hynčica, P., Śárovec, D. (2018): Slovenské politické strany optikou konceptu novosti. Acta Fakulty filozofické Západočeské univerzity v Plzni 10(2-3), 7-34, https://doi.org/10.24132/actaff.2018.10.2-3.1

Charlot, M. (1986): The June 1984 European Elections. Paris, Publications de la Sorbonne.

Charvát, J. (2007): Současný politický extremismus a radikalismus. Praha, Portál.

Irwin G. (1995): Second-order or third-rate?: Issues in the campaign for the elections for the European Parliament 1994. Electoral Studies 14(2), 183-199, https://doi.org /10.1016/0261-3794(95)96843-7.

Jesuit, D. (2003): The Regional Dynamics of European Electoral Politics: Participation in National and European Contests in the 1990s. European Union Politics 4(2), 139-164, https://doi.org/10.1177/146511650300400 2001.

Kaniok, P., Havlík, V. (2016): Populism and euroscepticism in the Czech Republic: Meeting friends or passing by? Romanian Journal of European Affairs 16(2), 20-35.

Klíma, M., Outlý, J. (2010): Volby do Evropského parlamentu 2009. V vybrané otázky př́ípravy, průběhu a výsledků voleb. Plzeň, Aleš Čeněk.

Kluknavská, A. (2012): Krajne pravicové strany v parlamentných vol'bách 2012 naSlovensku. Rexter časopis pro výzkum radikalismu, extremismu a terorismu 10(1), 1-35.

Kluknavská, A. (2013): Od Štúra k parazitom: Tematická adaptácia krajnej pravice v parlamentných vol'bách na Slovensku. Politologický časopis 20(3), 258-281, https://doi.org/10.5817/PC2013-3-258.

Kopecký, P., Mudde, C. (2002): The Two Sides of Euroscepticism: Party Positions on European Integration in East Central Europe. European Union Politics 3(3), 297-326, https://doi.org/10.1177/146511650200 3003002.

Kostelecký, T., Mikešová, R., Poláková, M., Čermák, D., Bernard, J., Šimon, M. (2016): Geografie výsledků parlamentních voleb: prostorové vzorce volebního chování v Česku 1992-2013. Praha, Sociologický ústav AV ČR.

Koubek, J. 2019. Volební chování českých velkoměst v historické perspektivě se zaměřením na výsledky levice. Praha, Masarykova demokratická akademie.

Kovář, J. (2013): The Supply Side of Second-Order Elections in the Czech Republic: A Light at the End of the Tunnel? Romanian Journal of European Affairs 13(1), 57-82.

Kovář, J. (2014): Europeizace volebních programů pro volby do EP. Politické vedy 17(3), 32-67.

Kovář, J., Kovář, K. (2014): Representation of Women in Second-order Elections: The Czech Republic and Slovakia Compared. Perspectives on European Politics and Society 15(1), 1-18, https://doi.org/10.1080/1570 5854.2013.793533.
Krivý, V., Feglová, V., Balko, D. (1996): Slovensko a jeho regióny: sociokultúrne súvislosti volebného správania. Bratislava, Nadácia Médiá.

Ladrech, R. (2002): Europeanization and Political Parties: Towards a Framework for Analysis. Party Politics 8(4), 389-403, https://doi.org/10.1177/135406880200800 4002.

Linek, L. (2013): Kam se ztratili voliči? Vysvětlení vývoje volební účasti v České republice v letech 1990-2010. Brno, Centrum pro studium demokracie a kultury.

Linek, L., Outlý, J., Tóka, G., Batory, A. (2007): Volby do Evropského parlamentu 2004. Praha, Sociologický ústav AV ČR.

Lipset, S. M., Rokkan, S. (1967): Party Systems and Voter Alignments: Cross-national Perspectives. London, Collier-Macmillan.

Lodge, J. (2010): The 2009 elections to the European Parliament. Basingstoke, Palgrave Macmillan.

Madleňák, T. (2012): Regionálna diferenciácia volebného správania na Slovensku (1998-2010). Bratislava, Veda.

Manokaran, E., Subhashini, S., Senthilvel, S., Muruganandham, R., Ravichandran, K. (2011): Application of multi criteria decision making tools and validation with optimization techniquecase study using TOPSIS, ANN \& SAW. International Journal of Management \& Business Studies 1(3), 112-115.

Maškarinec, P. (2017): A Spatial Analysis of Czech Parliamentary Elections, 2006-2013. Europe-Asia Studies 69(3), 426-457, https://doi.org/10.1080 /09668136.2017.1313962.

Maškarinec, P. (2019): The rise of new populist political parties in Czech parliamentary elections between 2010 and 2017: the geography of party replacement. Euroasian Geography and Economics 60(5), 511-547, https://doi.org/10.1080/15387216.2019.1691928.

Mikuš, R., Gurňák, D. (2016): Rómska otázka ako jeden z mobilizačných faktorov volebnej podpory krajnej pravice na Slovensku a v Mad'arsku. Geographia Cassoviensis 10(1), 29-46.

Mikuš, R., Gurňák, D., Máriássyová, A. (2016): Analýza volebnej podpory Mariána Kotlebu ako reprezentanta krajnej pravice v krajských vol'bách 2013. Sociológia 48(1), 48-70.

Opricovic, S., Tzeng, G. H. (2004): Compromise solution by MCDM methods: a comparative analysis of VIKOR and TOPSIS. European Journal of Operational Research 156(2), 445-455, https://doi.org/10.1016 /S0377-2217(03)00020-1.

Pink, M. (2012): Volební mapy České a Slovenské republiky po roce 1993: vzorce, trendy, proměny. Brno, Centrum pro studium demokracie a kultury.

Plešivčák, M. (2011). Regionálny obraz korelačnej závislosti medzi volebnými preferenciami a vybranými sociálnymi charakteristikami populácie Slovenska. Regionální studia 5(1), 2-16.

Plešivčák, M. (2015): First Two Elections to the European Parliament in Slovakia: Turnout and Results in Regional Perspective. Evropská volební studia 10(1), 14-32.

Przybyla, V. (2019): Vliv vybraných demografických charakteristik na volební chování na Slovensku v meziválečném období. Geografický časopis 71(2), 181-199, https://doi.org/10.31577/geogrcas.2019 .71.2.10 
Reif, K., Schmitt, H. (1980): Nine second-order national elections: a conceptual framework for the analysis of European election results. European Journal of Political Research 8(1), 3-44, https://doi.org/10.1111 /j.1475-6765.1980.tb00737.x.

Robert Schuman Foundation (2004): Survey on Evaluation of competences at the European and national levels (in EU member states), 28-30 April 2004.

Salo, S. (2014): Eurosceptics in the 2014 EP Elections. Protest Parties Mobilized on National Cleveages Between Globalization Winners and Losers. Helsinki, Finnish Institute of International Affairs.

Shih, H. S., Shyurb, H. J., Lee, E. S. (2007): An extension of TOPSIS for group decision making. Mathematical and
Computer Modelling 45(7-8), 801-813, https://doi.org /10.1016/j.mcm.2006.03.023.

Statistical Office of the Slovak Republic (2019): Elections and Referenda Database (2003-2019). Bratislava, Statistical Office of the Slovak Republic.

Šaradín, P. (2008): Teorie voleb druhého řádu a možnosti jejich aplikace v České republice. Olomouc, Univerzita Palackého v Olomouci.

Taggart, P., Szczerbiak, A. (2002): The Party Politics of Euroscepticism in EU Member and Candidate States. Brighton, Sussex European Institute.

Voda, P. (2015): Jaká je role postkomunismu? Volební geografie České a Rakouské republiky v letech 1990-2013. Brno, Centrum pro studium demokracie a kultury. 